\title{
Intellectual Capital: Measurement, RECOGNITION AND REPORTING
}

\author{
Christo Johannes Cronje and Sindiswa Moolman
}

School of Accounting Sciences, University of South Africa

Accepted: September 2012

\begin{abstract}
In the past few decades, the economy has moved from an industrial to a knowledge economy. Consequently, basic factors of production now no longer comprise only natural resources, capital and labour, but also intellectual capital. Despite the shift from an industrial to a knowledge economy, the accounting framework and financial reporting have not changed sufficiently to include intellectual capital. The research problem attempts to explore whether the theory of accounting should be modified for a standardised and comparable approach when accounting and reporting on intellectual capital. To solve the research problem, a literature review and content analysis on corporate annual reports were used. The results of this study indicate that the theory of accounting should be modified to ensure a standardised and comparable approach when accounting and reporting on intellectual capital in corporate annual reports.
\end{abstract}

Key words: intellectual capital, measurement, recognition, financial reporting, corporate annual reports

JEL: M410

\section{1}

\section{Introduction}

The business environment has seen and experienced a dramatic increase in the number of companies that hold intellectual capital in the form of knowledge, brands, competitive advantage, patents, customer relationships, human capital, research and development, and trademarks (Roslender, 2000:35). The major part of the market values of these companies lies in these intangible assets with relatively little value being associated with their tangible assets (Seetharaman, Sooria \& Saravanan, 2002: 128). Research shows that there is a growing awareness that intellectual capital adds significantly to the value of a business. However, the value in these assets remains hidden, and is not disclosed in the financial records of the organisations. Intellectual capital is classified as consisting of human, structural and relational capital (Abeysekera, 2003:422). This research focuses on these three classes of intellectual capital.

The reasoning behind the non-recognition of some of the intellectual capital is that these assets do not meet the recognition and measurement criteria in respect of their classification as intangible assets (IASB, 2011:A160-A161). The Conceptual Framework for Financial Reporting (IASB, 2011:A34) further states that the reason for non-recognition of these assets is the fact that there exists a degree of risk that the information about these assets will be a less than faithful representation of what the information purports to represent. This is as a result of inherent difficulties in either identifying the transactions and/or other events to be measured, or in devising and applying measurement and presentation techniques capable of conveying a message that is in line with those transactions and/or events. However, the Framework does allow the use of reasonable estimates to determine the amount to be disclosed. In this case, measurement and presentation may be performed through the use of reasonable estimates without undermining the reliability of the information. Nevertheless, when a reasonable estimate is not possible, then the item concerned will not be recognised in the statement of financial position (IASB, 2011:A35). As a result, a significant portion of a company's assets may not be reported in the financial statements of that company.

The IASB applies very strict requirements if an item is to be recognised as an asset in the 
financial statements. These requirements are necessary in order to ensure that it is possible to compare the financial information of different companies and to prevent management's manipulation of this information.

The increasing importance of intellectual capital and the growing number of companies that rely on these assets to create value have created a need to inform the market, the investors and the other stakeholders of the existence of intellectual capital (OECD, 2006: $5)$. Both the accounting and reporting of intellectual capital are, therefore, important if the stakeholders of a company are to be allowed the opportunity to make informed investment and other decisions.

\section{2}

\section{Research problem}

The research problem attempts to explore whether the theory of accounting should be modified for a standardised and comparable approach when accounting and reporting on intellectual capital. To solve the research problem, a literature review and content analysis on corporate annual reports of 40 companies listed on JSE Ltd were performed.

\section{3}

\section{Research method}

\subsection{The literature review}

The research focuses on prior literature of which the main focus has been on the measurement, recognition and disclosure of intellectual capital in financial reporting. Different South African and international journals, dissertations and books were used for this purpose. Studies on the analysis of the different values attributed to a business by the various users of the financial statements of the business were also reviewed.

\subsection{Content analysis}

To complement the literature review, a content analysis on the corporate annual reports of 40 companies listed on JSE Ltd on 12 May 2009 in terms of their market capitalisation was performed. Table 1 below provides a list of the 40 companies researched through content analysis.

Table 1

The 40 largest South African JSE listed companies as at 12 May 2009

\begin{tabular}{|c|c|c|c|}
\hline Rank & Company & Sector & $\begin{array}{l}\text { Market capitalisation } \\
\text { (ZAR billions) }\end{array}$ \\
\hline 1 & British Am Tobacco Plc & Tobacco & 445.5 \\
\hline 2 & BHP Billiton Plc. & Diversified natural resources & 425.3 \\
\hline 3 & Anglo American Plc & Mining holding and houses & 279.5 \\
\hline 4 & SAB Miller PIc & Beverages & 251.1 \\
\hline 5 & MTN Group Ltd & Telecommunications & 206.1 \\
\hline 6 & Sasol Ltd & Chemicals, oil and plastics & 193.3 \\
\hline 7 & Standard Bank Group & Banks, financial services & $\begin{array}{l}12+ \\
9.3\end{array}$ \\
\hline 8 & Anglo Platinum Ltd & Platinum & 118.6 \\
\hline 9 & AngloGold Ashanti Ltd & Gold & 111.4 \\
\hline 10 & Impala Platinum Holdings Ltd & Platinum & 107.9 \\
\hline 11 & Compagnie Fin Richemont & Luxury goods (Jewellery etc) & 88.4 \\
\hline 12 & Naspers Ltd & Pharmaceuticals & 76.0 \\
\hline 13 & FirstRand Ltd & Banks, financial services & 75.2 \\
\hline 14 & Gold Fields Ltd & Gold & 73.9 \\
\hline 15 & Absa Group Limited & Banks, financial services & 66.0 \\
\hline 16 & Telkom SA Ltd & Telecommunications & 59.4 \\
\hline 17 & Kumba Iron Ore Ltd & Iron & 59.4 \\
\hline 18 & Old Mutual Plc & Insurance, financial services & 49.5 \\
\hline 19 & Nedbank Group Ltd & Banks, financial services & 42.0 \\
\hline 20 & ArcelorMittal SA Ltd & Steel & 40.7 \\
\hline 21 & Harmony G M Co Ltd & Gold & 38.5 \\
\hline 22 & Sanlam Ltd & Insurance, financial services & 38.2 \\
\hline
\end{tabular}




\begin{tabular}{|l|l|l|c|}
\hline \multicolumn{1}{|c|}{ Company } & \multicolumn{1}{c|}{ Sector } & $\begin{array}{c}\text { Market capitalisation } \\
\text { (ZAR billions) }\end{array}$ \\
\hline 23 & Remgro Ltd & Diversified industrial & 31.4 \\
\hline 24 & Bidvest Ltd Ord & Diversified industrial & 31.4 \\
\hline 25 & African Rainbow Minerals & Diversified mining \& minerals & 28.3 \\
\hline 26 & Shoprite Holdings Ltd Ord & Retail, supermarkets & 28.2 \\
\hline 27 & Lonmin Plc. & Platinum & 27.4 \\
\hline 28 & RMB Holdings Ltd & Diversified & 26.9 \\
\hline 29 & Exxaro Resources Ltd & Steel & 26.8 \\
\hline 30 & Tiger Brands Ltd Ord & Diversified & 22.9 \\
\hline 31 & African Bank Investments & Financial services, retail, banks & 22.1 \\
\hline 32 & Reinet Investments SCA & Investment & 20.0 \\
\hline 33 & Growthpoint Prop Ltd & Property investment & 19.7 \\
\hline 34 & Liberty Holdings Ltd Ord & Insurance, financial services & 19.5 \\
\hline 35 & Investec Plc & Banks, financial services & 18.5 \\
\hline 36 & Liberty International Plc & Banks, financial services & 18.3 \\
\hline 37 & Pretoria Portland Cement & Cement & 17.8 \\
\hline 38 & Aspen Pharmacare Hldgs & Pharmaceuticals & 17.3 \\
\hline 39 & Truworths International & Retail & 16.4 \\
\hline 40 & Pick n Pay Stores Ltd & Retail, supermarkets & 16.3 \\
\hline
\end{tabular}

The content analysis framework used in this research is based on the approach of April, Bosma and Deglon (2003:166), while the data are analysed in order to draw inferences on the way in which South African companies recognise and report on intellectual capital.

The research will show how the companies investigated recognise and report the existence of the intellectual capital in their organisations. The analysis is based on the three categories or classes that have been identified by other researchers, namely human, structural and relational capital, and their performance indicators. According to Abeysekera (2003: 423), the identification of the intellectual capital that a company possesses is based on the intellectual capital attributes and performance indicators that are relevant to a specific intellectual capital category. The intellectual capital attributes of the three categories and their performance indicators reported on in the 40 corporate annual reports were analysed and illustrated. The overall reporting on the attributes of the three intellectual capital categories was further analysed and compared. Intellectual capital performance indicators that are used to

Table 2

Intellectual capital attributes

\begin{tabular}{|c|c|c|}
\hline Human capital attributes & Structural capital attributes & Relational capital attributes \\
\hline $\begin{array}{l}\text { - Knowledge } \\
\text { - Education } \\
\text { - Level of qualifications } \\
\text { - Skills } \\
\text { - Talent } \\
\text { - Work-related competencies } \\
\text { - Work-related expertise } \\
\text { - Innovativeness } \\
\text { - Proactiveness } \\
\text { - Entrepreneurial spirit } \\
\text { - Other attributes } \\
\text { OProfessionalism } \\
\text { o Experience }\end{array}$ & $\begin{array}{l}\text { Intellectual property } \\
\text { - Patents } \\
\text { - Copyrights } \\
\text { - Trademarks } \\
\text { - License agreements } \\
\text { - Other business rights } \\
\text { Infrastructure assets } \\
\text { - Management philosophy } \\
\text { - Corporate culture } \\
\text { - Management processes } \\
\text { - Information processes } \\
\text { - Network systems } \\
\text { - Research and development } \\
\text { - Leadership } \\
\text { - Financial relations } \\
\text { - Other attributes } \\
\text { ○ Technologies } \\
\text { ○ Business processes } \\
\text { ○ Key management attributes }\end{array}$ & $\begin{array}{l}\text { - Brands } \\
\text { - Customer list } \\
\text { - Customer loyalty } \\
\text { - Business collaborations } \\
\text { - Market share } \\
\text { - Supply chain } \\
\text { - Distribution channels } \\
\text { - Reputation } \\
\text { - Stakeholder relations } \\
\text { - Communication and information } \\
\text { - Mergers and acquisitions } \\
\text { - Joint ventures } \\
\text { - Other attributes } \\
\text { o Strategic partnerships } \\
\text { ○ Corporate image }\end{array}$ \\
\hline
\end{tabular}

Source: April et al. (2003:168) (adapted) 
measure intellectual capital, like personnel cost/revenue, intellectual property/total assets, market share and marketing cost/ revenue, were also researched and reported. Some extracts from the annual reports were reproduced in order to illustrate the nature and extent of the reporting on intellectual capital and its attributes by the companies researched. The research also included comparisons between the three categories of intellectual capital and their attributes. Table 2 above shows the framework used in the research.

\section{4}

\section{Literature review}

The term 'intellectual capital' is sometimes used interchangeably with intangible assets. However, financial reporting refers only to those intangible assets that are recognised by the International Accounting Standards Board (IASB), with these assets forming part of intellectual capital. Abeysekera (2003:422) further suggests that the definition of intellectual capital refers to intangibles not recognised in the financial statements. However, part of structural capital, namely intellectual property, is recognised in financial statements as it satisfies the separability requirement of the IASB (2011:161-162). Brännström and Giuliani (2009:23) describe intellectual capital as follows:

Intellectual capital $=$ identified intangible assets + purchased goodwill

The above description of intellectual capital supports the view that intangible assets form part of intellectual capital. Thomas (1997:5) argues that human capital refers to the capacity of individuals to provide solutions for their customers, while structural capital transforms expertise into the property of the group, and customer capital allows relations with customers to be perpetuated. In the early 1990s, writers and scholars identified the growing importance of intellectual capital as a source of long-term value creation for organisations (Roslender \& Fincham, 2004:179). During this time, literature on intellectual capital focused mainly on the need to report this type of capital as a separate asset in a business. This trend resulted in a debate on how best to do this in an accurate and reliable way in order to complement the financial information on strategic reporting. Other researchers, like Seetharaman et al. (2002:140) and Van der Meer-Kooistra and Zijlstra (2001:456), proposed a voluntary reporting that would support the financial reporting and assist investors in their decisionmaking. Varying views and debates emerged from different studies on intellectual capital accounting and reporting.

\subsection{Accounting debate on intellectual capital}

The debate on the existence of intellectual capital within a business was initially explained by means of the recognition and definition of the goodwill that is part of a business (Seetharaman, Balachandran \& Saravanan, 2002:131). The IASB (2011:A941-A943, A152), however, makes a distinction between the goodwill acquired in a business combination and internally generated goodwill.

During the IASB fieldwork and round-table discussions aiming at obtaining feedback on IFRS 3 Business Combinations project (IASB, 2008:382 and IASB, 2010:A97), there were debates in favour of and those against recognising intellectual capital in the annual financial statements of organisations. The IASB project resulted in the amendments to the treatment of goodwill acquired in a business combination and internally generated goodwill.

The IASB (2011:A152) refers to the goodwill acquired in a business combination as representing a payment made by an acquirer in anticipation of future economic benefits from assets that are not capable of being individually identified and separately recognised. The value of acquired goodwill is, therefore, determined by business combination transactions, and is recognised as an intangible asset in the statement of financial position of a company. The acquirer includes in goodwill the value of an acquired intangible asset that is not identifiable as of the acquisition date. For example, an acquirer may attribute value to the existence of an assembled workforce, which is an existing collection of employees that permits the acquirer to continue to operate an acquired business from the acquisition date. Because the assembled workforce is not an identifiable asset to be recognised separately 
from goodwill, any value attributed to it is included in the goodwill acquired.

Internally generated goodwill, on the other hand, refers to the expenditure incurred in order to generate future economic benefits that do not result in the creation of an intangible asset (IASB, 2010: A941). Accordingly, these assets are not recognised as assets in the financial statements, thus forming part of the intellectual capital that is expensed as a periodic cost in the statement of comprehensive income. An example of internally generated goodwill is the expenditure incurred in order to service a key customer so as to gain the customer's loyalty to the company's product. The result of incurring this expenditure is the customer's loyalty that may result in future economic benefits flowing into the company. However, these future economic benefits will not result in an identifiable intangible asset, because the company will have control neither over customer loyalty gained nor over future economic benefits that may flow from this gain. In addition, the measurement of intangible assets is also problematic.

Views by researchers such as Olsen, Halliwell and Gray (2007:2), who are against reporting the value of intellectual capital in the financial statements, are based on the above facts from the IASB. Furthermore, the IASB states that intellectual capital does not meet the definition of an asset and the recognition criteria thereof. As part of the recognition criteria, the cost of an item to be recognised should be reliably measured (IASB, 2011:A847). Therefore, measurement is fundamental to the IASB asset recognition rule.

The debate in favour of recognising intellectual capital in financial statements is based on the fact that the value of intellectual capital remains unreported to the users of company information (Rodov \& Leliaert, 2002: 323). The non-recognition of these assets in the financial statements therefore creates a gap between reported accounting and capital market values.

According to Swart (2006:137), unlike other assets, the value of internally generated goodwill is created over a period through a series of activities and it is not possible to link this value to a specific transaction. Intellectual capital therefore forms part of this internally generated value of the business, and therefore should be reported to capital providers and users of information. It emerged from the literature review that the argument in favour of recognising intellectual assets in financial reporting involves recognising that the true value of a company may be assessed only by taking intellectual capital into account (Marr, Schiuma \& Neely, 2004:553). It has also become clear from the above debate that there is both a need and a drive to establish new measures and ways in which to report on intellectual capital, in order to complement the financial reporting. Kukec (2007:28) refers to this kind of reporting as broad-based business reporting. Broad-based reporting provides investors and other stakeholders with both mandatory and contextual information and assists them to make informed decisions.

\subsection{Measurement of intellectual capital}

Intellectual capital assets are strategic resources that should be properly managed in order to derive maximum benefits from them. Effective management of these assets helps in their recognition, measurement and reporting (Holmen, 2005:2). Measuring the benefits gained from possessing intellectual capital and the value of these assets has both internal and external purposes. In terms of internal purposes, a company would measure intellectual capital in order to manage its resources more effectively, and will, thereby, minimise costs. On the other hand, measuring intellectual capital for external purposes would require verifiable information that signals the expected growth of the company to existing and potential investors, and to other external users of the information (Hunter, Webster \& Wyatt, 2005:3). The process of measuring intellectual capital for both internal and external purposes involves using financial and non-financial measurement methods.

\subsubsection{Financial measurement models for intellectual capital}

The existing financial measures used to assess the market value of an asset address the financial contribution made through intellectual capital. Researchers have identified a number of financial measures that include, inter alia, the discounted cash flow technique 
(DCF), relief-from-royalty, comparable transactions, avoided cost, adjusted present value, economic value added, value chain scoreboard, market-to-book ratio, and the capital asset pricing model. These financial techniques are used to measure the market value of a company for different purposes, and involve assigning a value to a company although the resultant value is not disclosed in the financial statements (Olsen, Halliwell \& Gray 2007:2). The value determined using some of the above models involves some degree of subjectivity, as some of these models involve the application of estimates such as cost of capital and rate of royalty. Therefore, these models are unsuitable for use to determine a value to be disclosed in the annual financial statements. The IASB encourages objectivity, as well as reliable and verifiable measurement in order to promote comparability across companies (IASB, 2009:9-16). Nevertheless, resultant values may be reported in the contextual disclosures of the corporate annual reports to communicate the unreported value of the organisation.

\subsubsection{Non-financial measurement models for intellectual capital}

In view of the difficulties in finding financial measures suitable for measuring the value of intellectual capital, researchers like Robert Kaplan and David Norton, as well as Leif Edvinsson (Starovic, CIMA \& Marr, 2005:811), developed non-financial measures such as the balanced score card and Skandia navigator in order to balance the need to report on these assets and the challenges involved in measuring them. Accordingly, the information obtained using these non-financial measures complements the information disclosed in the financial statements. Some of these non-financial measurements relate to measuring the different categories of intellectual capital, thereby making it easy to report the value pertaining to each category.

The measures developed include the balanced score card, Skandia navigator, value chain scorecard, and human capital accounting. Effective non-financial measures of intellectual capital will complement financial measures, provide both a feedback mechanism for actions and the information to develop new strategies, assist in weighing different courses of action, and enhance the management of the organisation (Holmen, 2005:2). Non-financial measures of intellectual capital provide information that will assist potential investors and other stakeholders as well as other users of the information, to make informed financial decisions relating to the company.

\subsection{Recognition of intellectual capital}

The cost of an item is recognised and disclosed in the annual financial statements, either in the statement of comprehensive income or in the statement of financial position, based on the minimum requirements set by the IASB for the presentation of financial information (IASB, 2011:A46-A49). The cost of acquiring intellectual capital should, therefore, be recognised in the financial statements if the financial statements are to meet these requirements.

\subsubsection{Recognition of intellectual capital in the statement of financial position}

Financial reporting operates around strict requirements that are statement of financial position biased. The process of recording a transaction in the accounting records commences with an analysis of its nature for the purposes of the statement of financial position recognition. Any item that does not meet the statement of financial position recognition requirement is immediately expensed in the statement of comprehensive income. IASB (2011:A48) notes that, in some cases, expenditure is incurred in order to generate future economic benefit, but still does not result in the creation of an intangible asset that meets the recognition criteria. Such expenditure is classified as internally generated goodwill, and is immediately expensed in the statement of comprehensive income.

\subsubsection{Recognition of intellectual capital in the statement of comprehensive income}

Cost incurred in the creation of an intellectual capital asset, but that does not result in the creation of an intangible asset as defined by the IASB, is recognised in the statement of comprehensive income. This cost is accounted for and disclosed as part of the administrative costs or as part of the operating costs of the 
company. Intellectual capital cost forms part of cash outflow and may be regarded as a depletion of assets (IASB, 2011:A45). In other words, costs of intellectual capital are regarded as contributing to the generation of revenue for a business, instead of adding to the value of the business. Because intellectual capital cost is expensed in the period in which it was incurred, it is difficult to trace this cost back to the book value of the company. However, the cost may, to some degree, be traced back to the value of the product or service that the company either produces or renders. Intellectual capital categories, their attributes and, sometimes, their performance indicators are used as the main account description for cost allocation, for example human resource or employee costs, research and development costs, and marketing costs.

\subsection{Intellectual capital disclosure and reporting}

The existence as well as the importance of intellectual capital as value drivers and strategic assets should be clearly communicated to the different users of company information. The different users of financial information have different needs and, therefore, financial reports are prepared in such a way as to satisfy these different needs. These different users include employees (including management), suppliers, customers, current and potential capital providers, government and the general public. These users may be grouped into internal and external users of information with the grouping influencing the type of information to be disclosed by an organisation (Cronjé, 2008:50). Accordingly, financial information is prepared for both internal and external reporting purposes.

According to Cronjé (2008:112-116), there are two areas of disclosure in respect of company information with one being based on the information produced by the mandatory financial information system (MFIS), as required by the various statutory bodies, and the other comprising the discretionary information system (DIS). In other words, the MFIS generates mandatory information, while the DIS generates contextual information based on the information needs of the different users (Cronjé, 2008:112-116). In addition, companies disclose information that supports the strategic objectives in their corporate annual reports. As a strategic asset, intellectual capital is used by some companies as a marketing tool to promote and enhance the reputation of the company. Companies also include intellectual capital attributes and performance indicators in their internal reports in order to assist management in their decision-making role.

The scope of financial reporting is, therefore, broader than just the financial statements, and includes information about the management stewardship of an entity's resources (IASB, 2011:A27). In addition to the capital providers, financial reporting is also aimed at all users of information about an entity's business and operations. This requires, in addition to financial statements, the disclosure of other financial information. Accordingly, information on an entity's financial performance and operations is disclosed in the corporate annual reports.

In December 2010, the IASB issued IFRS Practice Statement Management Commentary to accompany financial statements prepared in accordance with IFRS. One of the proposed principles for the preparation of management commentary is a report on the way in which those resources that are not presented in the financial statements may affect the performance of an entity (IASB, 2010:8). The IFRS Practice Statement also proposes that management commentary should include information that complements the financial statements, including information on relationships with major customers, and performance measures and indicators. However, it is essential that consistency in the reporting the performance measures and indicators be maintained in order to enhance the comparability of information within the industry (IASB, 2010:9-16). The issue of the IFRS Practice Statement paves the way for companies to report information on their intellectual capital. The proposed information that should be disclosed or presented in management commentary is similar to that which would be contained in the strategy document of the company. This Statement will provide a balance between internal and external reporting.

The disclosure of information in the corporate annual reports may be either mandatory or 
discretionary. Mandatory disclosures are governed by statutory and rule-making bodies and legislation including the Companies Act, the IASB, and the JSE LTD. The discretionary disclosures are, inter alia, determined by the strategic objectives of the company and the needs of the different users of information. Figure 4.1 illustrates the two areas of disclosures in the annual corporate reports.

Figure 1

The disclosures in corporate annual reports

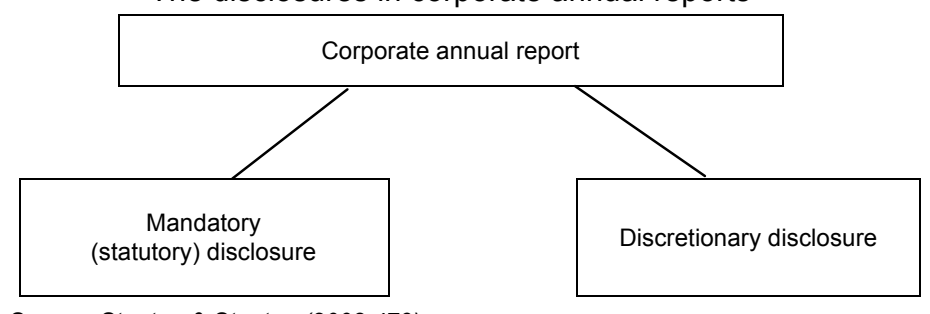

Source: Stanton \& Stanton (2002:479)

The King III Report (IOD, 2009:103) refers to annual corporate reporting as integrated sustainability reporting and disclosure. In terms of this report, reporting should be integrated across all areas of performance reflecting strategic decisions taken by a company. One of the Code of Governance principles refers to the importance of effective communication with stakeholders. According to Bukh (2002:53), the report on intellectual capital should communicate management's understanding of the company's strategy and value creation and should not only disclose performance indicators of general interest. As a result of the challenges in respect of disclosing information on intellectual capital under statutory disclosures, discretionary disclosures should be used for this purpose.
The next section deals with the content analysis results of the 40 companies listed on the JSE Ltd on 12 May 2009 and covers the current state of intellectual capital rating and reporting for these companies.

\section{5}

\section{Results of the content analysis}

The results of the content analysis research show how the companies investigated recognise and report the existence of the intellectual capital in their organisations. These results are summarised in Table 3 below, and cover the number of intellectual capital attributes reported by South African companies per each category.

Table 3

Number of attributes reported per intellectual capital category

\begin{tabular}{|l|c|c|c|}
\hline & $\begin{array}{c}\text { Human } \\
\text { capital }\end{array}$ & Structural capital & Relational capital \\
\hline Number of attributes in the model & 12 & 15 & 14 \\
\hline Number of companies & 40 & 40 & 40 \\
\hline Number of attributes reported & 321 & 197 & 280 \\
\hline Average number of attributes reported per company & 8 & 4.9 & 7 \\
\hline Maximum number of attributes reported & 11 & 11 & 11 \\
\hline Minimum number of attributes reported & 1 & 1 & 1 \\
\hline
\end{tabular}

April et al. (2003:167) (adapted)

Sixteen companies made reference to human capital when referring to their employees, while eleven companies referred to human resources. The rest of the 40 companies researched reported on individual human capital attributes without referring to either 
human capital or to human resources. Knowledge, levels of education and qualifications, skills, talent and experience were the most frequently reported human capital attributes in most of the corporate annual reports. Workrelated competencies and expertise, innovativeness and professionalism were reported on an average level, while professionalism and experience were included under 'other attributes'. This, in turn, means that a total of twelve attributes were researched under human capital.

A total of eleven structural capital attributes, three intellectual property attributes, and eight infrastructure capital attributes were reported on in the various corporate annual reports. However, there were additional attributes included in the 'other attributes' category with these being attributes that had not been included in the predetermined framework, resulting in fifteen attributes in total being researched. Technologies, license agreements and other rights, business processes and key management attributes were later included in the research. For the purpose of this study, license agreements and other rights were included under intellectual property, with the other two being included under infrastructure capital. The reason for this specific framework was to separate the intellectual assets recognised by the IASB from process assets. This was done in order to ensure comparability of the information presented.

Leadership proved to be the most reported infrastructure capital attribute, with thirty-six of the forty companies reporting on either the good or strong leadership that existed within their organisations. Information processes, network systems and financial relations were the least reported attributes. Corporate culture was the second most reported infrastructure capital attribute with some organisations referring to organisational, company or group culture. These different terms were all accepted as referring to corporate culture.

A total of fourteen relational capital attributes were researched in the forty corporate annual reports. Two more attributes, namely strategic partnerships and corporate image, were added to the initial twelve attributes researched based on the information presented in some of the corporate annual reports. Brand proved to be the most reported relational capital attribute with twenty-eight companies reporting on the different brands they possessed. Market share was the second highest reported attribute with twenty-five companies reporting on the level of their market share. However, based on the framework used and the fact that market share is always reported as a percentage, market share was recorded as both an attribute and as a performance indicator.

Figure 2 below depicts the breakdown in the reporting in terms of average percentage of reporting per intellectual capital category, namely human, structural and relational capital.

Figure 2

Average percentage of reporting per intellectual capital category

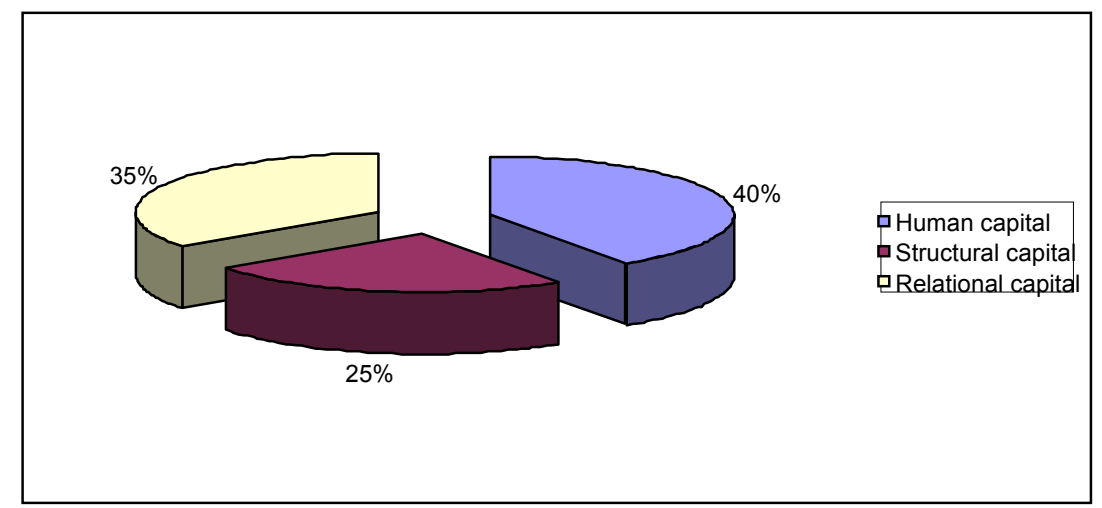

Source: Own 
The analysis on the extent to which the intellectual capital categories and their attributes were reported has indicated that, on average, human capital did receive significant attention in the annual reports of the 40 companies.

Overall, the companies in the study rated human capital at $40 \%(321 / 798)$, structural capital at 25 per cent $(197 / 798)$ and relational capital at $35 \%(280 / 798$ per cent $)$. These results are slightly different from the results of similar previous studies. Studies conducted by April et al. (2003:172-173) showed that there was more focus on relational capital than on the other two categories, with relational capital reported at 40 per cent and human capital at 30 per cent. This difference may be attributable to the fact that the framework used in this study for the intellectual capital attributes included other attributes not listed by other studies. There were more attributes included in the human capital category than in the other two categories. The framework used by April et al. (2003) was based on six human capital attributes and nine relational capital attributes, respectively, compared to the twelve and thirteen used in this study.

A greater emphasis on the reporting on human capital provides assurance to capital providers and other stakeholders that the company is in the hands of capable, highlyskilled and competent employees. Some of the companies referred to human capital and human resources when referring to their employees. The higher rate of relational capital may be attributable to the fact that most of the companies researched compete globally and, consequently, human and relational intellectual capital drivers are critical in order to give these companies a competitive advantage. Structural capital received less attention when compared to the other two, with this rate being further reduced when intellectual property assets were excluded.

The research results of this study overall indicate that the theory of accounting should be modified to ensure a standardised and comparable approach when accounting and reporting on intellectual capital in corporate annual reports.

The above conclusion is drawn as a result of the following factors:
- The nature of intellectual capital assets makes it difficult to trace the costs relating to their acquisition. Accordingly, their nature creates significant challenges in both the financial reporting and the management of these assets. Nevertheless, these challenges do not prevent companies from reporting on the existence, value and importance of these assets to both the users of financial information and other stakeholders.

- It was found that those arguments that favour the recognition of intellectual capital revolve around the acknowledgement of a need to capture the nature and value of intellectual capital and other intangible assets that add value to the overall value of the business in financial reporting. The arguments against the recognition of intellectual capital are mainly from an accounting perspective, based on the IASB Framework for the Preparation and Presentation of Financial Statement, IFRSs, and IASs. However, it emerged clearly from both these sets arguments that there is a need to develop a reporting framework that will assist to strike a balance between gaining the advantages of reporting on intellectual capital and achieving the fair presentation of financial information.

- It may, therefore, be concluded that measuring, recognising and disclosing information on intellectual capital is not limited by the requirements of statutory or mandatory disclosures. Financial statements fall under these disclosures but, in addition to these disclosures, there are also several disclosures that may be used to communicate information to the users that are within management's discretion. These discretionary disclosures form part of the corporate annual reports of a company and companies should, therefore, be encouraged to use these discretionary disclosures in order to communicate information on intellectual capital.

- Although the cost of intellectual capital is immediately expensed and is regarded as a reduction in the asset value (cash and cash equivalents), the cost incurred in respect of these assets and their attributes contribute to the market value of the company concerned. It may also be concluded that, 
as a result of its flexibility and the fact that the discipline is less constrained, it is the management accounting discipline that should be used to report the value of intellectual capital using financial and nonfinancial measurement models. In addition, the discipline should also be used to report the performance of these assets and their attributes.

- The results of the content analysis showed that intellectual capital reporting still lacks prominence. When reported, intellectual capital assets are referred to in qualitative terms and in terms of their attributes. The reason for this is partly because there has been little progress made in measuring intellectual capital assets. This view is supported by the fact that, because it is not possible to measure intellectual capital assets reliably, these property assets were explicitly reported upon in the annual financial statements of those companies holding them.

\section{References}

ABEYSEKERA, I. 2003. Intellectual accounting scorecard: Measuring and reporting intellectual capital. Journal of American Academy of Business, 3(1):422-427.

APRIL, K., BOSMA, P. \& DEGLON, D. 2003. IC measurement and reporting: Establishing a practice in SA mining. Journal of Intellectual Capital, 4(2):165-180.

BRÄNNSTRÖM, D.B. \& GIULIANI, M. 2009. Intellectual capital and IFRS3: A new disclosure opportunity. Journal in Knowledge Management, 7(1):21-23.

BUKH, P.N. 2002. Commentary: The relevance of intellectual capital disclosure: A paradox. Accounting, Auditing \& Accountability Journal, 16(1):49-56.

CRONJÉ, C.J. 2008. Corporate annual reports (CARs): Accounting practices in transition. VDM Verlag Dr, Müller, Saarbrücken, Germany.

HOLMEN, J. 2005. Intellectual capital reporting. Management Accounting Quarterly, 6(4):1-6.

HUNTER, L., WEBSTER, E. \& WYATT, A.L. 2005. Measuring intangible capital: A view of current practice. Australian Accounting Review, 15(2):1-18.

IASB. 2008. International Financial Reporting Standards (IFRSS). 2008: including International Accounting Standards (IASs) and Interpretations as at 30 November 2007. Vol 1A \& 1B.London: IASB.

- Basis for Conclusions on IAS 38: Intangible Assets.

IASB. 2009. Management Commentary. Exposure Draft 2009/6.

IASB. 2010. IFRS Practice statement: management commentary. A framework for presentation.

IASB. 2010. International Financial Reporting Standards (IFRSs). 2010: including International Accounting Standards (IASs) and Interpretations as at 30 November 2009. Vol. 1A. London: IASB.

- Conceptual Framework for Financial Reporting.

- IFRS 3: Business Combinations.

IASB. 2011. International Financial Reporting Standards (IFRSs). 2011: including International Accounting Standards (IASs) and Interpretations as at 30 November 2010. Vol. 1A. London: IASB.

- Conceptual Framework for Financial Reporting.

- IFRS 3: Business Combinations.

- IAS 38: Intangible Assets.

INSTITUTE OF DIRECTORS IN SOUTHERN AFRICA (IOD). 2009. Code of Governance Principles for South Africa. King Committee on Governance.

KUKEC, S. 2007. Accounting for the non-tangibles. Charter, 78(1):28-29.

MARR, B., SCHIUMA, G. \& NEELY, A. 2004. Intellectual capital: Defining key performance indicators for organizational knowledge assets. Business Process Management Journal, 10(5):551-569.

OLSEN, M.G., HALLIWELL, M. \& GRAY, R.P. 2007 Intangible value: Delineating between shades of grey. Journal of Accountancy, 203(5):66-71.

ORGANISATION FOR ECONOMIC CO-OPERATION AND DEVELOPMENT, Corporate affairs division, directorate for financial and enterprise. 2006. Intellectual assets and value creation: Implications for 
corporate reporting. Paris: OECD. Available at: http://www.oecd.org/dataoecd/2/40/37811196.pdf. [accessed 2008-09-24].

RODOV, I. \& LELIAERT, P. 2002. FiMIAM: Financial method of intangible assets measurement. Journal of Intellectual Capital, 3(3):323-336.

ROSLENDER, R. 2000. Accounting for intellectual capital: A contemporary management accounting perspective. Management Accounting, 78(3):34-37.

ROSLENDER, R. \& FINCHAM, R. 2004. Intellectual capital accounting in the UK. Accounting, Auditing \& Accountability Journal, 17(2):178-209.

SEETHARAMAN, A., BALACHANDRAN, M. \& SARAVANAN, A.S. 2002. Accounting treatment of goodwill: Yesterday, today and tomorrow: Problems and prospects in the international perspective. Journal of Intellectual Capital, 5(1):131-152.

SEETHARAMAN, A., SOORIA, H.H.B.Z. \& SARAVANAN, A.S. 2002. Intellectual capital accounting and reporting in the knowledge economy. Journal of Intellectual Capital, 3(2):128-148.

STANTON P \& STANTON, J. 2002. Corporate annual reports: Research perspectives used. Accounting, Auditing \& Accountability Journal, 15(4):478-500.

STAROVIC, D., CIMA \& MARR, B. 2005. Understanding corporate value: managing and reporting intellectual capital. London: Cranfield University.

SWART, J. 2006. Intellectual capital: Disentangling an enigmatic concept. Journal of Intellectual Capital, 7(2):136-159.

THOMAS, A.S. 1997. Intellectual capital: The new wealth of organisations. Knowledge Management, 67: $1-10$.

VAN DER MEER-KOOISTRA, J. \& ZIJLSTRA, S.M. 2001. Reporting on intellectual capital. Accounting, Auditing \& Accountability Journal, 14(4):456-476. 